\title{
HIGH PREVALENCE OF EHRLICHIA CANIS IN DOGS IN VAN, TURKEY
}

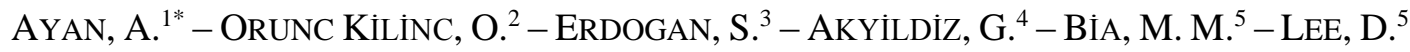 \\ ${ }^{I}$ Department of Genetics, Faculty of Veterinary Medicine, Van Yuzuncu Yil University \\ 65080 Van, Turkey \\ ${ }^{2}$ Özalp Vocational School, Van Yuzuncu Yil University, 65100 Van, Turkey \\ ${ }^{3}$ Department of Internal Medicine, Faculty of Veterinary Medicine, Aydin Adnan Menderes \\ University, 09100 Aydin, Turkey \\ ${ }^{4}$ Genkord Health and Biotechnology Services Inc., 34212 Istanbul, Turkey \\ ${ }^{5}$ Department of Parasitology, Parasite Research Center and Parasite Resource Bank, School of \\ Medicine, Chungbuk Natioanal University, Korea \\ Corresponding author \\ e-mail: adnanayan@yyu.edu.tr; phone: +90-432-225-1128/21549
}

(Received 20 $0^{\text {th }}$ Nov 2019; accepted $30^{\text {th }}$ Jan 2020)

\begin{abstract}
Tropical and subtropical regions have seen an alarming increase in vector-borne diseases especially tick-borne diseases. Ehrlichiosis is one of the most important vector-borne disease from a zoonotic perspective and it can be even more lethal in dogs and humans a compromised immune system. This study was conducted to determine the prevalence and molecular characterization of E. canis in Van province of Turkey. A total of 387 blood samples were collected from dogs in Van veterinary clinics in 2019. Extracted DNAs were run through Nested PCR using the appropriate primers. A total of 79 samples out of 387 were E. canis positive at 389 bp revealed by Nested PCR. Sanger method was used for DNA sequencing of two selected positive samples. Phylogenetic analysis revealed that relevant amplicon was $100 \%$ compatible with 16S RNA gene isolated from E. canis in many geographical regions.
\end{abstract}

Keywords: ehrlichiosis, molecular characterization, Nested PCR, phylogenetic analyses, prevalence, tick

\section{Introduction}

Tick-borne diseases in cats and dogs have seen an upward trend in recent years posing public health risks especially for those having close contact with their pets (Claerebout et al., 2013; Maia et al., 2014). Tick-borne bacterial and protozoal infections affect the dogs in many parts of the world depending on the distribution of vectors (Aktas et al., 2015). Ehrlichiosis is a zoonotic disease mentioned at the top of list and its pathogenicity becomes more lethal in immunocompromised dogs and humans (Perez et al., 2006). Ehrlichia sp. are obligate intracellular parasites infecting the blood cells. The etiologic agent of canine monocytic ehrlichiosis (CME) is E. canis should be resides in canine monocytes and macrophages. Depending on the immune status of the host, CME may be asymptomatic or symptomatic causing severe anemia, leukopenia, thrombocytopenia, fever, and even death especially in dogs with poor immunity (Kakoma et al., 1994; Mathew et al., 1996; Oliveira et al., 2019). Vector-borne diseases especially those involving ticks as vectors are highly prevalent in tropical and subtropical regions (Springer et al., 2019). To date, DNAs of E. chaffeensis, E. ewingi, and E. muris have been isolated from canine blood from South Central United States, Europe and Costa Rica 
(Skotorczak, 2003; Little et al., 2010; Springer et al., 2019). In our previous study, E. canis was identified in the ticks collected from stray dogs in Van region of Turkey (Ayan et al., 2019). However, the prevalence and molecular characterization of E. canis in stray dogs were not carried out in Van province. Therefore, the present study was conducted to determine the prevalence and molecular characterization of E. canis in stray dogs in the Van province, Turkey so that proper strategies may be devised to control the infection.

\section{Materials and Methods}

\section{Collection of samples}

Blood samples were collected in EDTA vacutainers from 387 stray dogs presented at three veterinary clinics (Kent Veterinary Clinic (121 samples), Cetin Veterinary clinics (129 samples), and Tamara Pet Veterinary clinic (137 samples)) in central Van in 2019 as shown in Figure 1. Blood samples were transported to the laboratory in cold chain at $-20^{\circ} \mathrm{C}$ for further analysis.

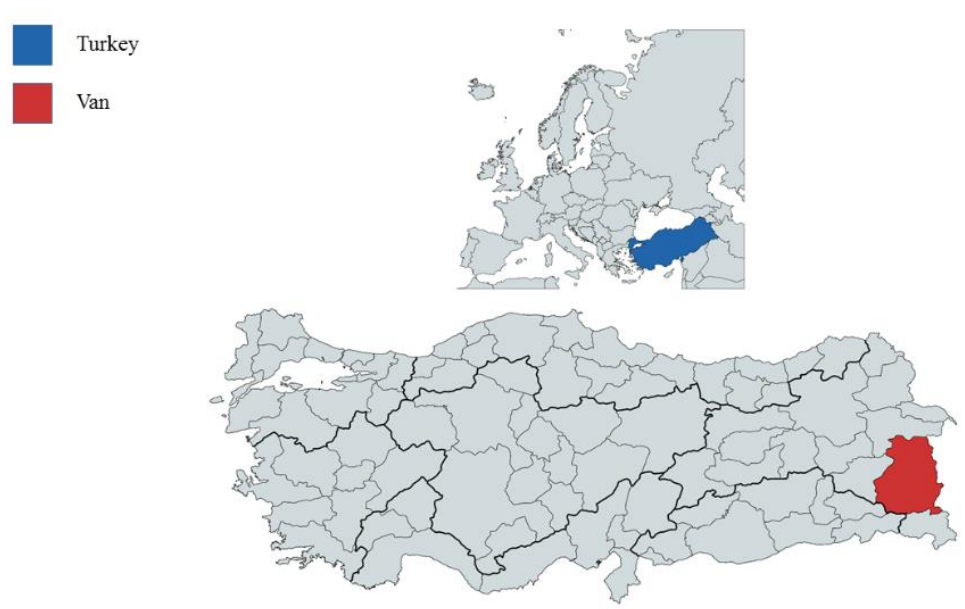

Figure 1. Map of Turkey showing the localities of the investigation area for collection Ehrlichia canis from dogs. In 2019, 387 specimens were collected from 3 veterinary clinics in Van centre in Van province of Turkey

\section{DNA extraction}

Extraction of DNA from each blood sample was carried out using Invitrogen PureLink $^{\mathrm{TM}}$ Genomic DNA Mini Kit (USA, K182002) according to the procedure outlined in the kit protocol. Extracted DNAs were stored at $-20^{\circ} \mathrm{C}$ until PCR amplification.

\section{PCR amplification}

The 16S rRNA gene region of E. canis was amplified using nested PCR. The first amplification primers: ECC (5' AGAACGAACGCTGGCGGCAAGC-3') and ECB (5' CGTATTACCGCGGCTGCTGGCA-3'). The second amplification primers: ECAN5 (5- CAATTATTTATAGCCTCTGGCTATAGGA-3') and HE3 (5'TATAGGTACCGTCATTATCTTCCCTAT-3') (Murphy et al., 1998; Alves et al., 2014; 
Makino et al., 2016). For this purpose, each reaction contained 12.5 pmol forward primer, 12.5 pmol reverse primer, 0.625 U of HOT FIREPol DNA polymerase (Solis BioDyne, Tartu, Estonia), 1X PCR Buffer (Solis BioDyne, Tartu, Estonia), $1 \mathrm{mM} \mathrm{MgCl} 2$ (Solis BioDyne, Tartu, Estonia), $120 \mu \mathrm{M}$ dNTP (Solis BioDyne, Tartu, Estonia), extracted DNA samples (50-200 ng) and DNase/RNase Free Distilled Water (Gibco Thermo Fisher Scientific, Waltham, MA USA) were mixed to make a final volume of $25 \mu \mathrm{L}$. PCR was performed in Eppendorf Mastercycler ${ }^{\circledR}$ pro automatic thermal cycler. In the first stage of Nested PCR: $95^{\circ} \mathrm{C}$ for $15 \mathrm{~min}$ and 37 cycles of $95^{\circ} \mathrm{C}$ for $1 \mathrm{~min}$ and 30 seconds, annealing at $55^{\circ} \mathrm{C}$ for $1 \mathrm{~min}$ and 30 seconds and $72^{\circ} \mathrm{C}$ for $1 \mathrm{~min}$ and 30 seconds, followed by a final extension $72^{\circ} \mathrm{C}$ for $10 \mathrm{~min}$. In the second stage of Nested PCR: $95^{\circ} \mathrm{C}$ for $15 \mathrm{~min}$ and 40 cycles of $95^{\circ} \mathrm{C}$ for $1 \mathrm{~min}$, annealing at $65^{\circ} \mathrm{C}$ for $1 \mathrm{~min}$ and $72^{\circ} \mathrm{C}$ for $1 \mathrm{~min}$, followed by a final extension $72^{\circ} \mathrm{C}$ for $10 \mathrm{~min}$. The amplified products were separated on a $1.5 \%$ agarose gel and visualized by Safe-T stain (BioShop, Canada) staining under imaging system (Syngene Bio Imaging System).

\section{DNA sequencing and phylogenetic analysis}

Two positive samples, confirmed by PCR, were selected at random and DNA (forward and revers) sequence was determined according to the Sanger sequencing method. Forward and reverse sequences of each sample were compared using the Bioedit Sequence Allignment Editor Program (Hall, 1999). Finally, the resulting DNA sequences were compared with the similar sequences in NCBI database using BLAST. The evolutionary history was inferred by using the Maximum Likelihood method based on the Kimura 2-parameter model (Kimura, 1980). The tree with the highest log likelihood $(-951,11)$ is shown. The percentage of trees in which the associated taxa clustered together is shown next to the branches. Initial tree(s) for the heuristic search were obtained automatically by applying Neighbor-Join and BioNJ algorithms to a matrix of pairwise distances estimated using the Maximum Composite Likelihood (MCL) approach, and then selecting the topology with superior log likelihood value. A discrete Gamma distribution was used to model evolutionary rate differences among sites (5 categories $(+\mathrm{G}$, parameter $=0,1908))$. The tree is drawn to scale, with branch lengths measured in the number of substitutions per site. The analysis involved 15 nucleotide sequences. All positions containing gaps and missing data were eliminated. There were a total of 362 positions in the final dataset.

Evolutionary analyses were conducted in MEGA X (Kumar et al., 2018).

\section{Ethical considerations}

All the procedures involved in the study were approved by the local ethics committee of Van Yuzuncu Yil University, Van, Turkey vide letter no. VAN YUHADYEK/2019/10 dated 31 October 2019.

\section{Results}

In the first stage of nested PCR, Ehrlichia spp. specific bands of 458 bp were obtained. Nested PCR revealed that E. canis specific 389 bp bands were obtained in 79 of 387 samples Agarose gel images for amplicons of each samples in the PCR shows in Figure 2.

The results showed that a $20.41 \%$ positivity of $E$. canis detected in Van province. Two of the 79 samples were randomly selected for sequence analysis. The DNA sequences 
obtained from Sanger sequencing were $100 \%$ compatible with the E. canis specific $16 \mathrm{~S}$ rRNA gene in NCBI database. The sequences of two positive samples obtained from Bioedit Sequence Allignment Editor program were 359 bp and 367 bp, respectively. The tree with the highest log likelihood (-943.20) is shown. The percentage of trees in which the associated taxa clustered together is shown next to the branches. Initial tree(s) for the heuristic search were obtained automatically by applying Neighbor-Join and BioNJ algorithms to a matrix of pairwise distances estimated using the Maximum Composite Likelihood (MCL) approach, and then selecting the topology with superior log likelihood value. The tree is drawn to scale, with branch lengths measured in the number of substitutions per site. The analysis involved 16 nucleotide sequences. All positions containing gaps and missing data were eliminated. There were a total of 357 positions in the final dataset. Phylogenetic analysis of E. canis in dogs from Van province of Tukey showed that there were no genetic differences between the two samples based on the relevant amplicons as shown in Figure 3.

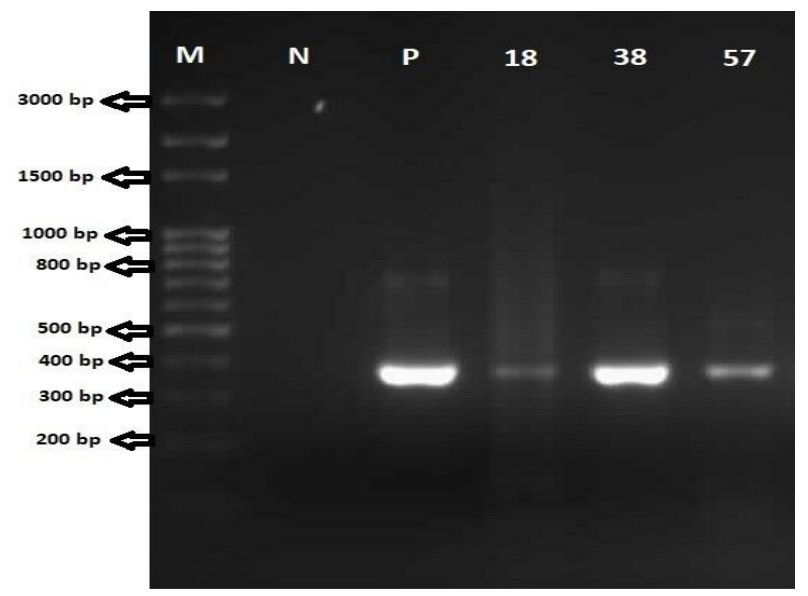

Figure 2. Agarose gel images for amplicons of each samples in the PCR. (M: Marker, P: Positive control, 18, 38, 57: Positive samples)

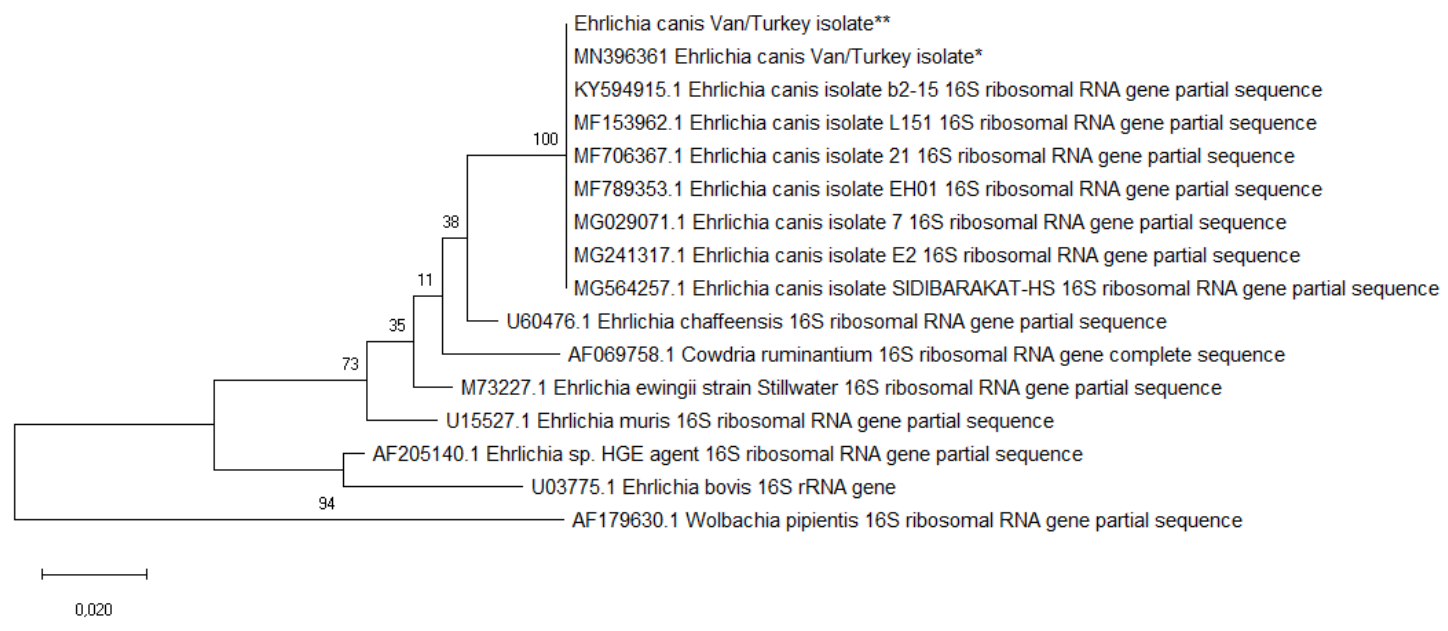

Figure 3. Molecular Phylogenetic analysis by Maximum Likelihood method of 16S rRNA gene of E. canis. Two samples (*: MN396361 Ehrlichia canis Van/Turkey isolate, **: Ehrlichia canis Van/Turkey isolate) in the same node as seen in the tree 


\section{Discussion}

Tick-borne diseases, a cosmopolitan problem resulting in subclinical or severe infections in their hosts, are increasingly affecting the public and animal health around the globe (Hofmann-Lehmann et al., 2016). Zoonotic importance of canine tick-borne pathogens has increased in the recent years as dogs play a major role as reservoir host, Ehrlichiosis being one of those diseases (Ozubek et al., 2018). In the present study, the prevalence of $E$. canis in dogs in Van province was investigated on a molecular basis. At the end of the study, E. canis DNA was detected in 79 (20.41\%) of 387 blood samples collected. This is the first report that describes the molecular detection of Ehrlichiosis in dog populations in Van, Turkey. Previous studies have reported the prevalence of E. canis in dogs in different parts of Turkey and the world alike, including some reports investigated the prevalence based on molecular studies. According to the molecular studies conducted in Turkey, the prevalence of E. canis 23 out of 219 blood samples in Diyarbakır was (10.5\%) (Ozubek et al., 2018), E. canis was not detected in 133 samples from Konya (Guo et al., 2017), 58 out of 400 blood samples in Kayseri was (14.5\%) (Duzlu et al., 2014), 37 out of 757 samples collected from different provinces (Elazığ, Diyarbakır, Erzurum, Ankara, Nevşehir, Adapazarı, İzmit, Mersin, Giresun, İzmir) was 4.9\% (Aktas et al., 2015), 47 out of 400 blood samples in Thrace was $11.75 \%$ (Cetinkaya et al., 2016), 3 out of 12 dogs with clinical symptoms in Ankara (Unver et al., 2005). Similarly, Hofmann-Lehmann et al. (2016) reported that 14 out of 249 blood samples collected from Sicily (Italy) and Portugal were Anaplasma platys and E. canis positive whereas the DNA of E. canis was not detected in samples from Swirzerland, Spain, and Terasa and Bologna regions of Italy. In addition, Cardoso et al. (2016) reported E. canis in 5.8\% of 103 blood samples in Luanda region of Angola and Alho et al. (2017) found E. canis in $3.1 \%$ of 64 blood samples in Qatar. In contrast, E. canis DNA was not found in 97 blood samples collected from Iraq (Otranto et al., 2019). In this study, Ehrlichia infection in Van, Turkey was found to be $20.41 \%$ prevalent that is high. There may be different reasons underlying the high prevalence of related infections in the region. Inadequate external parasite spraying in dogs and the presence of $R$. sanguineus in the region can be considered as the main reasons for the high prevalence of Ehrlichiosis. The importance of this disease is increasing all over the world including Turkey. It is noteworthy that global warming, environmental and ecological changes, and the existence of appropriate habitats increase the impact of ticks that results in frequent emergence and re-emergence of tick-borne diseases of zoonotic importance (Inci et al., 2016).

Vector hemoparasites can be diagnosed by examining the clinical signs and blood staining methods, however, diagnostic may arise attributed to the similarities in symptoms and microscopic structures of the etiologic agents. Consequently, test based on serological and molecular techniques should be preferred in order to diagnose the hemoparasites. Nonetheless, it becomes difficult to extricate between current and previous exposure to pathogens that might result in false negative results in case of acute ehrlichiosis. Therefore, diagnosis based on molecular tests is the best option (Neer et al., 1998; Little et al., 2010; Aktas et al., 2015; Springer et al., 2019). The most common method used to diagnose ehrlichiosis is one-step PCR analysis to amplify the 16S rRNA gene region, however, its sensitivity is low. Therefore, diagnosis through Nested PCR increases the sensitivity and is more relaiable (Bulla et al., 2004; Macieira et al., 2005; Nakaghi et al., 2008; Santos et al., 2009). However, non-specific amplification among the strains of Ehrlichia species due to highly conserved 16S rRNA gene and higher risk of DNA cross-contamination are inevitable in this method (Labruna et al., 2007). 
Consequently, the sequencing and phylogenetic analyses are important so as to prove the accuracy of the results in addition to identify the molecular similarity among the species (Sumner et al., 2000).

E. canis, a proteobacter that causes ehrlichiosis, possess a 16S rRNA gene consisting of $1380 \mathrm{bp}$ in size. In our study, we identified and amplified a gene of $390 \mathrm{bp}$ in size that is repeatedly employed in the molecular diagnosis of E. canis. The DNA sequence analysis of the region revealed the identification of a subtype of $E$. canis that is distributed in different geographical regions. The DNA sequence analysis of our E. canis DNA samples showed $100 \%$ similarities with those of NCBI database isolated from E. canis in different geographies such as Elazı̆̆/Turkey (Accession number: KY594915), Panama (Accession number: MF789353), Egypt (Accession number: MG564257), Romania (Accession number: MG241317), India (Accession number: MF706367), Mexico (Accession number: MG029071), and Brazil (Accession number: MF153962). All genomic analysis is possible using new generation sequencing technologies along with the identification of new or unknown subtypes of proteobacter E. canis.

\section{Conclusion}

In conclusion, this molecular study confirmed the presence and prevalence of E. canis in dogs in Van province of Turkey. This shows that Ehrlichiosis in dogs in this region may pose threats to public health especially in immunocompromised people. We believe that the density of dog population and lack of effective control of ticks especially in stray dogs are the possible predisposing factors for this high prevalence of ehrlichiosis in dogs in Van, Turkey. In order to determine the zoonotic potential of ehrlichiosis, it is necessary to compare the genetic factors and genetic proximity of ehrlichiosis in humans with that of dogs. As the tick-borne diseases are increasing around the globe, we believe that the control of ticks in domestic animal and effective treatment of animals infested with ticks will be key to preventing tick-borne diseases. Since the Van province shares its border with Iran, ticks and tick-borne diseases in this region have potential to create an international problem. In addition, changing climatic conditions and human migration have created variability especially in vectors of vector-borne diseases. Therefore, further studies in this area should not only focus $R$. sanguineus, but also other tick species by molecular methods. In addition, scientists in the countries sharing the border in the region should carry out joint and collaborative studies especially in terms of vector diseases and the molecular proximity of the agents should be demonstrated.

\section{REFERENCES}

[1] Aktas, M., Özübek. S., Altay, K., Sayin Ipek, N. D., Balkaya, İ., Utuk, A. E., Kırbas, A., Şimsek, S., Dumanli, N. (2015): Molecular detection of tick-borne rickettsial and protozoan pathogens in domestic dogs from Turkey. - Parasites \& Vectors 8: 157.

[2] Alho, A. M., Lima, C., Latrofa, M. S., Colella, V., Ravagnan, S., Capelli, G., Carvalho, L. M., Cardoso, L., Otranto, D. (2017): Molecular detection of vector-borne pathogens in dogs and cats from Qatar. - Parasites \& Vectors 10: 298.

[3] Alves, R. N., Rieck, S. E., Ueira-Vieira, C., Labruna, M. B., Beletti, M. E. (2014): Isolation, in vitro propagation, genetic analysis, and immunogenic characterization of an Ehrlichia canis strain from southeastern Brazil. - Journal of Veterinary Science 15(2): 241-8. 
[4] Ayan, A., Alic Ural, D., Erdogan, H., Orunc Kilinc, O., Gültekin, M., Ural, K. (2019): Prevalance and Molecular Characterization of Giardia duodenalis in Livestock in Van, Turkey. - International Journal of Ecosystems and Ecology Science 9(2): 289-296.

[5] Bulla, C., Takahira, R. K., Araújo, J. P., Trinca, L. A., Lopes, R. S., Wiedmeyer, C. E. (2004): The relationship between the degree of thrombocytopenia and infection with Ehrlichia canis in an endemic area. - Veterinary Research 35(1): 141-146.

[6] Cardoso, L., Oliveira, A. C., Granada, S., Nachum-Biala, Y., Gilad, M., Lopes, A. P., Sousa, S. R., Vilhena, H., Baneth, G., (2016): Molecular investigation of tick-borne pathogens in dogs from Luanda, Angola. - Parasites \& Vectors 9: 252.

[7] Cetinkaya, H., Matur, E., Akyazi, I., Ekiz, E. E., Aydin, L., Toparlak, M. (2016): Serological and molecular investigation of Ehrlichia spp. and Anaplasma spp. in ticks and blood of dogs, in the Thrace Region of Turkey. - Ticks and Tick-borne Diseases 7(5): 706714 .

[8] Claerebout, E., Losson, B., Cochez, C., Casaert, S., Dalemans, A. C., De Cat, A., Madder, M., Saegerman, C., Heyman, P., Lempereur, L. (2013): Ticks and associated pathogens collected from dogs and cats in Belgium. - Parasites \& Vectors 6: 183.

[9] Duzlu, O., Inci, A., Yildirim, A., Onder, Z., Ciloglu, A. (2014): The investigation of some tick-borne protozoon and rickettsial infections in dogs by Real Time PCR and the molecular characterizations of the detected isolates. - Ankara Üniversitesi Veteriner Fakültesi Dergisi 61: 275-282.

[10] Guo, H., Sevinc, F., Ceylan, O., Sevinc, M., Ince, E., Gao, Y., Moumouni, P. F. A., Liu, M., Efstratiou, A., Wang, G., Cao, S., Zhou, M., Jirapattharasate, C., Ringo, A. E., Zehng, W., Cao, S. (2017): A PCR survey of vector-borne pathogens in different dog populations from Turkey. - Acta Parasitologica 62(3): 533-540.

[11] Hall, T. A. (1999): BioEdit: a user-friendly biological sequence alignment editor and analysis program for Windows 95/98/NT. - Nucleic Acids Symposium Series 41: 95-98.

[12] Hofmann-Lehmann, R., Wagmann, N., Meli, M. L., Riond, B., Novacco, M., Joekel, D., Gentilini, F., Marsilio, F., Pennisi, M. G., Lloret, A., Carrapiço, T., Boretti, F. S. (2016): Detection of "Candidatus Neoehrlichia mikurensis" and other Anaplasmataceae and Rickettsiaceae in Canidae in Switzerland and Mediterranean countries. - Schweiz Arch Tierheilkd 158: 691-700.

[13] Inci, A., Yildirim, A., Onder, O., Doganay, M., Aksoy, S. (2016): Tick-Borne Diseases in Turkey: A Review Based on One Health Perspective. - PLOS Neglected Tropical Diseases 10(12): e0005021.

[14] Kakoma, I., Hansen, R. D., Anderson, B. E., Hanley, T. A., Sims, K. G., Liu, L., Bellamy, C., Long, M. T., Baek, B. K. (1994): Cultural, molecular and immunological characterization of the etiologic agent for atypical canine ehrlichiosis. - Journal of Clinical Microbiology 32: 170-175.

[15] Kimura, M. (1980): A simple method for estimating evolutionary rate of base substitutions through comparative studies of nucleotide sequences. - Journal of Molecular Evolution 16: 111-120.

[16] Kumar, S., Stecher, G., Li, M., Knyaz, C., Tamura, K. (2018): MEGA X: Molecular Evolutionary Genetics Analysis across computing platforms. - Molecular Biology and Evolution 35: 1547-1549.

[17] Labruna, M. B., McBride, J. W., Camargo, L. M., Aguiar, D. M., Yabsley, M. J., Davidson, W. R., Stromdahl, E. Y., Williamson, P. C., Stich, R. W., Long, S. W., Camargo, E. P., Walker, D. H. (2007): A preliminary investigation of Ehrlichia species in ticks, humans, dogs, and capybaras from Brazil. - Veterinary Parasitology 143(2): 189-95.

[18] Little, S. E., O’Connor, T. P., Hempstead, J., Saucier, J., Reichard, M. V., Meinkoth, K., Meinkoth, J. H., Andrews, B., Ullom, S., Ewing, S. A., Chandrashekar, R. (2010): Ehrlichia ewingii infection and exposure rates in dogs from the southcentral United States. - Veterinary Parasitology 172: 355-360. 
[19] Macieira, D. B., Messick, J. B., Cerqueira, A. M., Freire, I. M., Linhares, G. F., Almeida, N. K., Almosny, N. R. (2005): Prevalence of Ehrlichia canis infection in thrombocytopenic dogs from Rio de Janeiro, Brazil. - Veterinary Clinical Pathology 34(1): 44-48.

[20] Maia, C., Ferreira, A., Nunes, M., Vieira, M. L., Campino, L., Cardoso, L. (2014): Molecular detection of bacterial and parasitic pathogens in hard ticks from Portugal. Ticks and Tick-borne Diseases 5: 409-14.

[21] Makino, H., Sousa, V. R. F., Fujimori, M., Rodrigues, J. Y., Dias, A. F. L. R., Dutra, V., Nakazato, L., de Almeida, A. B. P. F. (2016): Ehrlichia canis detection in dogs from Várzea Grande: a comparative analysis of blood and bone marrow samples. - Ciência Rural 46(2): 310-314.

[22] Mathew, J. S., Ewing, S. A., Barker, R. W., Fox, J. C., Dawson, J. E., Warner, C. K., Murphy, G. L., Kocan, K. M. (1996): Attempted transmission of Ehrlichia canis by Rhipicephalus sanguineus after passage in cell culture. - American Journal of Veterinary Research 57: 1594-1598.

[23] Murphy, G. L., Ewing, S. A., Whitworth, L. C., Fox, J. C., Kocan, A. A. (1998): A molecular and serologic survey of Ehrlichia canis, Ehrlichia chaffeensis and E. ewingii in dogs and ticks from Oklahoma. - Veterinary Parasitology 79(4): 325-339.

[24] Nakaghi, A. C. H., Machado, R. Z., Costa, M. T., André, M. R., Baldani, C. D. (2008): Canine ehrlichiosis: Clinical, hematological, serological and molecular aspects. - Ciencia Rural 38(3): 766-770.

[25] Neer, T. (1998): Canine Monocytic and Granulocytic Ehrlichiosis. - In: Greene, C. E. (ed.) Infectious diseases of the dog and cat. 2nd ed. Philadelphia, USA: WB Saunders; 1998. pp. 139-147.

[26] Oliveira, B. C. M., Ferrari, E. D., Viol, M. A., André, M. R., Machado, R. Z., de Aquino, M. C. C., Inácio, S. V., Gomes, J. F., Guerrero, F. D., Bresciani, K. D. S. (2019): Prevalence of Ehrlichia canis (Rickettsiales: Ehrlichieae) DNA in Tissues From Rhipicephalus sanguineus (Acari: Ixodidae) Ticks in Areas Endemic for Canine Monocytic Ehrlichiosis in Brazil. - Journal of Medical Entomology 56(3): 828-831.

[27] Otranto, D., Iatta, R., Baneth, G., Cavalera, A. M., Bianco, A., Parisi, A., Dantas-Torres, F., Colella, V., McMillan-Cole, A. C., Chomel, B. (2019): High prevalence of vector-borne pathogens in domestic and wild carnivores in Iraq. - Acta Tropica 197: 105058.

[28] Ozubek, S., Ipek, D. N. S, Aktas, M. (2018): A molecular survey of rickettsias in shelter dogs and distribution of Rhipicephalus sanguineus (Acari: Ixodidae) sensu lato in Southeast Turkey. - Journal of Medical Entomology 55(2): 459-463.

[29] Perez, M., Bodor, M., Zhang, C., Xiong, Q., Rikihisa, Y. (2006): Human infection with Ehrlichia canis accompanied by clinical signs in Venezuela. - Annals of the New York Academy of Sciences 1078: 110-117.

[30] Santos, F., Coppede, J. S., Pereira, A. L. A., Oliveira, L. P., Roberto, P. G., Benedetti, R. B. R., Zucoloto, L. B., Lucas, F., Sobreira, L. (2009): Molecular evaluation of the incidence of Ehrlichia canis, Anaplasma platys and Babesia spp. in dogs from Ribeirão Preto, Brazil. - The Veterinary Journal 179(1): 145-148.

[31] Skotorczak, B. (2003): Canine ehrlichiosis. - Ann Agric Environ Med 10: 137-141.

[32] Springer, A., Montenegro, V. M., Schicht, S., Vrohvec, M. G., Pantchev, N., Balzer, J., Strube, C. (2019): Seroprevalence and Current Infections of Canine Vector-Borne Diseases in Costa Rica. - Frontiers in Veterinary Science 6: 164.

[33] Sumner, J. W., Storch, G. A., Buller, R. S., Liddell, A. M., Stockham, S. L., Rikihisa, Y., Messenger, S., Paddock, C. D. (2000): PCR Amplification and Phylogenetic Analysis ofgroESL Operon Sequences from Ehrlichia ewingii and Ehrlichia muris. - Journal of Clinical Microbiology 38(7): 2746-2749.

[34] Unver, A., Rikihisa, Y., Borku, K., Ozkanlar, Y., Hanedan, B. (2005): Molecular detection and characterization of Ehrlichia canis from dogs in Turkey. - Berliner und Münchener tierärztliche Wochenschrift 118(7-8): 300-304. 